\title{
SCIENCE FICTION IN RUSSIAN LITERATURE AND CINEMA
}

\author{
Dr. Arş. Gör. Emek YILDIRIM ŞAHIN*
}

\begin{abstract}
In the $20^{\text {th }}$ century, science and technology, which penetrated into every individual's life after the Enlightenment and Industrial Revolution, gained a complete dominance over foremostly daily life of the humankind and all other fields by demonstrating a progress further than the ground covered throughout the human history. This process at the same time has caused various kinds of appearances within the world of thought of the humanity. By considering the positive and negative effects of science and technology on the human life, utopic and dystopic narratives were produced. The last 200-250 years of the human history have gone by witnessing that these ideas created debates, concepts, theories, facts, and practices not only within the fields of art but also in the social and political arenas. Particularly, it is an undeniable truth regarding the social and political influences of the literary and visual instances of science fiction, which is one of these concepts. In general, an investigation concerning the $20^{\text {th }}$ century adventure of science fiction at the same time offers an opportunity for a depth discussion in regards to the social and political atmosphere of the $20^{\text {th }}$ century as well. For this reason, by this article, while the science fiction works in Russian literature and cinema and the conditions cause to exhibit them will be handled, on the other hand, it will be tried to disclose the hints of the social and political circumstances of the era.
\end{abstract} dystopia.

Keywords: Russian literature, Russian cinema, science fiction, Soviet Union, utopia,

\section{RUS EDEBIYATINDA VE SINEMASINDA BILIM KURGU}

\section{ÖZ}

Aydınlanma ve Sanayi Devrimi ile her bireyin yaşamına nüfuz eden bilim ve teknoloji 20. yüzyılda insanlık tarihi boyunca kat ettiği mesafeden daha fazla bir gelişim göstererek insanlığın başta gündelik hayatı olmak üzere tüm alanlar üzerinde bütünlüklü bir hâkimiyet elde etmiştir. $\mathrm{Bu}$ süreç aynı zamanda insanlığın düşünce dünyasında da çok çeşitli tezahürlere neden olmuştur. Bilim ile teknolojinin insan yaşamına etkilerinin olumlu ve olumsuz yönleri göz önüne alınarak ütopik ve distopik anlatılar üretilmiştir. Insanlık tarihinin son 200-250 senesi bu düşüncelerin sadece sanatsal alanlarda değil aynı zamanda toplumsal ve siyasal alanlarda da çok çeşitli tartışmalara, kavramlara, kuramlara, olgulara ve pratiklere yol açı̆̆ına şahitlikle geçmiştir. Özelikle, bu kavramlardan biri olan bilimkurgunun yazınsal ve görsel sanatlardaki örneklerinin toplumsal ve siyasal etkileri de yadsınamaz bir gerçekliktir. Genel olarak bilimkurgunun 20. yüzyıl serüvenine dair bir inceleme aynı zamanda 20. yüzyılın toplumsal ve siyasal atmosferi hakkında derinlikli bir irdeleme imkânı da sunmaktadır. Bu sebeple, bu çalışma ile Rus edebiyatında ve sinemasında bilimkurgu eserleri ve ortaya çıkış koşulları ele alınırken, bir yandan da dönemin toplumsal ve siyasal ahvalinin ipuçları izhar edilmeye çalışılacaktır.

Anahtar Kelimeler: Rus edebiyatı, Rus sineması, bilimkurgu, Sovyetler Birliği, ütopya, distopya.

\footnotetext{
- Artvin Çoruh Üniversitesi/Hopa İktisadi Ve İdari Bilimler Fakültesi/Siyaset Bilimi Ve Kamu Yönetimi Bölümü/Siyaset Ve Sosyal Bilimler Anabilim Dalı, emekyildirim@artvin.edu.tr, Orcıd ID: 0000-0002-9101-8243
} 


\section{Introduction}

The Construction of mass utopia was the dream of the twentieth century. It was the driving ideological force of industrial modernization in both its capitalist and socialist forms. The dream was itself an immense material power that transformed the natural world, investing industrially produced objects and built environments with collective, political desire. Whereas the night dreams of individuals express desires thwarted by the social order and pushed backward into regressive childhood forms, this collective dream dared to imagine a social world in alliance with personal happiness and promised to adults that its realization would be in harmony with the overcoming of scarcity for all (BuckMorss, 2000: 10).

The meaning of science fiction in Russian is 'научная франтастика' that is to say 'scientific fantasy'. The first use of this word was in 1894 in the editorial note of the fifth volume of the Journal of Nature and People (Природа и люди) (Banerjee, 2012: 1). The general use of the word as 'science fiction', which is the source of this meaning in many languages, was first used in 1926 by Hugo Gernsback, who is the source of inspiration of the Hugo Award as the most important science fiction award in literature in the world now, after many years from Russians. When it needs to mention Russia and science fiction, first of all Yevgeny Ivanovich Zamyatin and his famous novel We (Мы) and Andrei Arsenyevich Tarkovsky and his famous film Solaris (Солярис) often come to minds. Moreover, any other names and their works can occur rarely. On the one hand, it is a lesser-known subject by intellectuals, artists, and left movements while for decades they mingle with Russian/Soviet geography, culture, history, political culture, literature, arts, cinema, philosophy, sciences, daily life, intellectual life, etc. It is also so ironic that Russian/Soviet culture, arts, literature are known less, although there is a widespread cliché that almost everyone has read 'Russian classics'. On the other hand, nearly for two centuries, the geographies, which have a sophisticated science and art tradition, deal with science fiction as the merging extent of science and arts, although for a long while mostly it has been accepted as the reading for children and youngsters and undervalued by who has involved in engagements that are more 'serious'. Subsequently, by replacing of francophone influence in the 1930s-1940s with the anglophone one in the 1960s-1970s upon the artistic and intellectual life, main science fiction works began to come from the Anglo-American world. Consequently, the science fiction literature foremostly has started to become popular with writers and their works from Anglo-American geography such as Ursula K. Le Guin, George Orwell, Aldous Huxley and Isaac Asimov. In addition to that, for instance, some novels such as Lord of the Flies of William Golding and The Iron Heel of Jack London are the worldwide famous works lesser known with their science fiction aspect.

Within this context, the Russian science fiction literature and cinema, which are so significant not only in Russia but also throughout the world, have continued as lesser known across the country for a long time, until recent times. The known works are the works used for anti-Soviet propaganda of the West such as We of Zamyatin. Whereas proto-science fiction works written by Russian writers and intellectuals under the influence of science fiction works written within a utopic and/or dystopic framework arisen after Enlightenment and Industrial Revolution in the West began to be written 
and read in the $18^{\text {th }}$ century. For example, Nikolay Gavrilovich Chernyshevsky, who was tracing Prince Mikhail Mikhailovich Shcherbatov and Prince Vladimir Fyodorovich Odoyevsky as two important names not only of the Russian Enlightenment but also of the Russian proto-science fiction as well, and his famous work What Is To Be Done? (Что делать?) ${ }^{1}$, which is not a complete science fiction but has significant science fiction attributes with a Fourierian background and has had a great impact upon the Russian science fiction literature for years, are good instances for early Russian science fiction endeavors. Furthermore, Pyotr Alexeyevich Kropotkin, who is a leading name of the anarchist movement not only in Russia but also in the world, described this novel as "a flag for Russian youth" (Yıldırım, 2016: 66). As a matter of fact, in this novel, the fourth dream of Vera Pavlovna substantially contains a utopic science fiction aspect, and it has affected some large and small facts and cases occurring in the Russian political and social atmosphere for a long time. Since then, starting with proscience fiction works in $18^{\text {th }}$ century, the Russian science fiction works have always had a great impact not only upon Russian art but also on political and social facts occurring on national and international bases. Therefore, by this article, it is aimed to study not only artistic but also political and social background of Russian science fiction in literature and cinema by considering the science fiction works produced since the late $19^{\text {th }}$ century.

\section{Russian Science Fiction Literature}

Many good, clever people have written books on the subject of how one should live on this earth so that all people may be happy. According to them, the most important thing is to organize workshops according to a new system. l'd like to see if together we can establish the new system they prescribe (Chernyshevsky, 1989: 190-191).

The first science fiction works in Russian literature were The Newest Journey (Новейшее путешествие) written in 1784 by Vasily Alekseyevich Lyovshin and the texts of significant Russian scientist Konstantin Eduardovich Tsiolkovsky². Moreover, Tsiolkovsky was the father of rocket science and astronautics theory besides having a great impact on Russian science fiction before and after the October Revolution. ${ }^{3}$ Another name in the $19^{\text {th }}$ century was Faddey Venediktovich Bulgarin who wrote science fiction stories by using many technological tools, devices and items discovered

\footnotetext{
1 Vladimir llyich Lenin inspired the title of his work What Is to Be Done? from the famous novel of Chernyshevsky because the fact that Lenin was impressed a lot by Chernyshevsky and his work What Is To Be Done?

2 'Cosmism' (Космизм) was a movement of thought developed and led by Tsiolkovsky. Cosmism aimed to create a universal proletariat image composed of physical labor, technological development and collective power of humanity. It can be said that cosmism has affected not only Russian science fiction but also generally Russian literature and intellectual life in many ways. Two names who influenced from cosmism were philosopher Nikolay Aleksandrovich Berdyayev and writer Andrei Platonov.
}

3 The Star KETs (Звезда КЭЦ) was written in 1940 by Alexander Belyayev in memory of Tsiolkovsky, and 'KETs' means 'Konstantin Eduardovich Tsiolkovsky' (КЭЦ: Константин Эдуардович Циолковский). 
after decades and became a popular writer with his vivid imagination. On the one hand, it is necessary to indicate that many socialist works, which were written by writers as $\mathrm{H}$. G. Wells, Edward Bellamy and Karl Ballod and composed of such topics as science, technology, modernism, urbanization, industrialization, etc., reached Russian society of $19^{\text {th }}$ century through Russian intellectuals relating with the Western world of ideas, were translated into Russian and became very popular among literate people. On the other hand, the $20^{\text {th }}$ century became an era that science fiction writers and works increased quantitatively and qualitatively in Russia. Within the era before the October Revolution, Red Star (Красная звезда) written by Alexander Aleksandrovich Bogdanov $^{4}$ and published in 1908 and its sequel Engineer Menni (Инженер Мэнни) published in 1913 are an important serial that could detail a communist life style foreseen to construct in future and give the hint of the footstep of the revolution having an arrival. The great impact of Russian futurism and Russian avangard movement, which was born through trust and hope towards science and technology as the main facts composing the spirit of the era, upon the Russian intellectual life before and after the Revolution is another factor providing the proper conditions for nourishing, growing and blossoming forth of Russian literature. On the other hand, in the novel Red Star, of which the name of the protagonist is Lenni, at an early date, Bogdanov could predict the troubles of post-industrial societies by telling the plans and attempts to invade other planets because of the depletion of natural resources as a result of the combat of human beings against the nature continuing during the socialist system as well in addition to that he describes utopian and dystopian sides of the socialist system constructed on Mars together (Gezgin, 2016: 86-89).

After the Revolution, it could be seen that Soviet literature acquired a science fiction aspect in the course of the construction of the USSR and new Soviet culture, of course sometimes in a positive notion and sometimes in a negative notion. On the one hand, the first and foremost one among the works written with a negative approach was We (Mы) written by Zamyatin in 1920. Although it was put forward that it did not describe the Soviet Union, with this work, he could foresee the spirit of the oncoming times and the new circumstances in the Soviet Union in days to come even before the revolution, as well as Bogdanov also predicted a socialist/communist system in his work Red Star before the revolution and the socialist system. Another debate upon this work of Zamyatin is about the inspiration of Orwell in his work 1984 dated 1947 and Huxley in his work Brave New World dated 1932.

On the other hand, the first instance having a positive approach was Aelita (Аэлита) written in 1922 and Hyperboloid of Engineer Garin (Гиперболоид инженера Гарина) written in 1926 by Alexei Nikolayevich Tolstoy. At the same time, both of them were adapted into a screenplay, and the movie of Aelita filmed in 1924 became one of the leading movies of Russian science fiction cinema. Moreover, today there are more than 14 awards in the field of science fiction literature in Russia, and one of them is the Aelita Award, during which a science fiction festival is also

4 From these two works of Bogdanov who was a significant name both for Russian/Soviet revolutionary movement and the times before and after the Revolution, Red Star was firstly translated in Turkish and published in Turkey in 2009 and Engineer Menni in 2012. 
organized. Another name from the 1920s and 1930s was Alexander Romanovich Belyaev who was also referred to as 'Jules Verne of the Soviet'. Belyaev wrote tens of science fiction books, which were well-known by both young and old people, including Amphibian Man (Человек-амфибия) first published in 1928, The Head of Professor Dowell (Голова профрессора Доуэля) serialized in 1925. Mainly he wrote about the benefits and harms of the development of science and technology. Another writer who wrote about similar issues in the works of Belyaev was Mikhail Afanasyevich Bulgakov. The organ transplantation, which was used by Belyaev in his work The Head of Professor Dowell, was also dealt by Bulgakov in his work Heart of a Dog (Собачье сердие). This book was written and banned in 1925, and in 1987 it could be published. Nevertheless, Bulgakov wrote his book The Fatal Eggs (Роковые яйца) in 1924 that actually includes criticism of science and technology, and it could be published immediately in 1925. Alexander Vasilievich Chayanov is also another significant writer of the 1920s because he wrote about collectivism, socialism and the Soviet ideal of that era within a science fictional atmosphere. In his book, The Journey of my Brother Alexei to the Land of Peasant Utopia (Путешествие моего брата Алексея в страну крестьянской утопии), protagonist Alexei fell asleep in 1921 and woke up in 1984, and he starts to describe the time of 1984. It is interesting that on the same date, Chayanov foresaw a utopia, although Orwell predicted a dystopia.

After the 1920s and 1930s, there emerged a significant gap in the science fiction literature quite a while because of the reasons arisen as the outcomes of the social and cultural structuring process of the Soviet Union, checking all written texts through the Writers' Union and the destructive effect of the World War II. Before the World War, probably the last science fiction work was The Land of the Нарру (Страна счастливых) written by Yan Leopoldovich Larri in 1931, and until the death of Joseph Stalin any other science fiction work was not produced because he claimed that these works were not appropriate for the socialist realism and Proletkult $t^{5}$ as the new senses of art of the Soviet Union, and so all artistic works out of this frame encountered with a strict oppression. For that reason, science fiction works could come forth even in 1960s. In this period, it was seen that some other discussions beside the science and technology started to take place within the Russian/Soviet science fiction literature. Various kinds of items, issues including psychoanalysis, ecology, anthropology, gender issues, metaphysics, mysticism, ethics, ontology and aesthetics were included in the

\footnotetext{
${ }^{5}$ Proletkult is the abbreviation of 'proletarskaya kultura' (пролетарская культура), which means culture of the proletariat. This concept was born from the Proletarian Cultural-Enlightenment Organizations (Пролетарские культурно-просветительные организации) found after February Revolution in 1917. Before the October Revolution, this movement had spread the seeds by particularly tracing the ideas of such prominent Russian artists as Maxim Gorky, Alexander Bogdanov and Anatoly Lunacharsky. By the October Revolution, it could reach the masses and became widespread much more. It was as an experimental artistic movement mainly constituted of socialist realist ideas and revolutionary discourses in the Soviet Union to establish an approach belonging to the working class in arts because of the existing apprehension that arts produced until then had been belonging to culture of the bourgeoisie and subsequent to the Revolution there needed to construct a new kind of culture and arts regarding to the working class and socialist system recently started to build. Moreover, it also became the pattern for the dominant culture of the Soviet ideology from the early years of construction of the USSR up to beginning of the 1930s.
} 
science fictional works from now on. Science fiction re-arose by becoming of cosmology and astronomy as important parts of the Soviet culture due to the increase of space researches on the one hand and influence of realm of freedoms arisen in the Soviet world of ideas as a consequence of de-Stalinization policies on the other hand. Moreover, for a long time, in Soviet literature, the most popular works of both official and unofficial/underground literature were either satirical/humorous or science fictional. For instance, science fiction works took place in the pages of popular science journals/magazines, and the writers were included in the staff of these journals/magazines such as Technology Youth (Техника-молодежи), Change (Смена), Science and Life (Наука и жизнь), Searcher (Искатель), Around the World (Вокруг света), Young Guard (Молодая гвардия) and Knowledge is Power (Знаниесила). After this kind of relief, it is likely that first significant work was The Andromeda Nebula (Туманность Андромеды) of Ivan Antonovich Efremov writing in 1957, and it was published in the journal Technology Youth in 1958. It is also a sign that science fiction finally re-appeared in the field of Russian/Soviet literature. Furthermore, some parts of Solaris of Stanislaw Lem were published in the journal of Knowledge is Power in 1961, and it attracted intense attention of the audience. Thus, science fiction retrieved its old popularity again. By the 1960s and 1970s, science fiction began to be effective in the fields of both literature and cinema. Strugatsky Brothers as one of the significant names of Russian/Soviet science fiction literature are among the most popular science fiction writers not only in Russia but also around the world even today. Although Arkady and Boris Natanovich Strugatsky have their own separate works, their fame is actually due to the works they write together. The leading one is Roadside Picnic (Пикник на обочине) dated 1971, and this book was also adapted into Tarkovsky's famous film Stalker (Сталкер) in 1979. In addition to it, some other popular works of Strugatsky Brothers are Noon: $22^{\text {nd }}$ Century (Полдень. XXII век), Snail on the Slope (Улитка на склоне), The Doomed City (Град обреченный), Hard to Be a God (Трудно быть богом), One Billion Years after the End of the World (3a миллиард лет до конца света) and Monday Begins on Saturday (Понедельник начинается в субботу). Up to the 1980s and 1990s, the state of affairs of Russian/Soviet science fiction literature has continued in this way. By the collapse of the USSR and the establishment of the Russian Federation, under the new political, economic, social and cultural circumstances, not only science fiction has still preserved its sphere of influence among the audience but also it has begun to include different kinds of issues or styles such as especially with themes including fantastic items. Some significant writers and their works belonging to this era were Victor Pelevin and his book Omon Ra (Омон Pa) ${ }^{6}$, Sergei Vasilievich Lukyanenko and Night Watch (Ночной дозор) series, Dmitry Alexeevich Glukhovsky and Metro 2033 (Метро 2033) series, Vladimir Sorokin and Day of Oprichnik (День опричника) ${ }^{7}$, and Andrei Victorovich

$6 \mathrm{OMON}(\mathrm{OMOH})$ is the abbreviation of Special Police Forces in Russian Federation, as 'Special Purpose Mobile Unit' (Отряд милиции особого назначения). It is probable that Pelevin uses such an ironic title for his book because of being a person who gets into trouble with the police too often.

7 Opriçnik was the name of guards of Ivan IV or a.k.a. Ivan the Terrible (Иван Грозный). They became the symbol of tyrannical government of Ivan the Terrible. 
Rubanov and Chlorophyll (Хлорофилия). Furthermore, it can be stated in a broad sense that although science fiction works of Soviet times were mainly based on hope and utopian drive for development of science and technology in future, science fiction works of the Russian Federation period has a more pessimistic sense with dystopian narration especially parallel with the dystopic atmosphere of the 1990s in Russia. Additionally, it is also crucial to indicate that there are two pioneering figures of science fiction all over the world, and these are Stanislaw Lem and Isaac Asimov, both of who were born within Soviet geography but later started to live in different lands. In fact, these two famous science fiction writers are actually originated from Russian/Soviet culture. Moreover, while Tarkovsky adapted Solaris of Lem into a film in 1972, Lem had a great impact upon the Russian intellectual life as well. Asimov is also one of the most influential writers of the Russian science fiction by his works translated into Russian during and after the Soviet period. Nevertheless, it is clear that in general the main difference distinguishing Russian/Soviet science fiction from science fiction genres of other countries is basically shaped by the hope for future arisen by enthusiasm of a new kind of collective spirit and creativity, as Efremov also explains in the manifesto he wrote upon Soviet science fiction:

To try to lift the curtain of mystery over these roads, to speak of scientific achievements yet to come as realities, and in this way to lead the reader to the most advanced outposts of science - such are the tasks of science fiction, as I see them. But they do not exhaust the aims of Soviet science fiction: its philosophy is to serve the development of the imagination and creative faculty of our people as an asset in the study of social life; and its chief aim is to search for the new, and through this search to gain an insight into the future (Landon, 2002: 72).

\section{Russian Science Fiction Cinema}

Initially, Vladimir llyich Lenin, who is the foremost figure of the Soviet system and one of the significant people for Russian society for decades, had a great influence on both literature and cinema not only within his daily life but also in his world of ideas and political struggle in his entire life (Yıldırım, 2016: 66-67). For that reason, he emphasized the importance of cinema beside the literature from the beginning of the construction of the Soviet Union after the October Revolution. He was aware that cinema could access the masses more easily and more extensively with respect to the other fields of art, and to deliver political, social and cultural messages of the new system could be comprehended by the masses in a carter by the help of visual images. It was one of the easiest way to reach people by the Party and administrative units in the Soviet Union, which was constructed with the ideal due to creating a new kind of society by people from different cultures within wide geography (Yıldırım, 2014: 279280). Moreover, Lenin claimed that a socialist hegemony would be possible by using propaganda and agitation efficiently through cinema. Cinema came into prominence also because of the fact that the majority of the population lived in rural and they were uneducated or poorly educated. By means of cinema, not only the masses could get political, social and cultural training but also the Soviet ideology, which was the cement of the new society by carrying required propaganda to people, could spread throughout the country and fill the gap left from economic and political spheres. For this aim, it was 
given a substantial room for Russian/Soviet cinema, and essential facilities were used every means available to reach the masses. Consequently, the paradigm of Russian cinema, which is kept up with not only in Soviet geography but also across the world with a great interest, was born. Since the 1920s, tens of films from various genres that went down of the history of cinema have been produced. Among them, one of these genres is Russian/Soviet science fiction cinema that produces many prominent films as well. Furthermore, although Russian/Soviet science fiction cinema is composed of films predominantly adapted from literary works as a reflection of Russian/Soviet science fiction literature, every film has its own interpretation, meaning, narration, image world, and realm of senses, emotions and ideas through approaches of directors towards stories apart from the works they adapted.

One of them is Aelita: Queen of Mars (Аэлита - королева Марса), which is not only the first science fiction film in Russia but also one of the prominent iconic films of Russian/Soviet cinema. This film was directed by Yakov Alexandrovich Protazanov in 1924 and based on the work with the same title of Alexei Nikolayevich Tolstoy dated 1922 (Christensen, 2000). Subsequently, it also became a masterpiece that affects works in all fields of art including science fictional narrations all across the world as well as in Soviet geography. For instance, German director Fritz Lang inspired from this film, and there are many similarities between his cult film Metropolis shot in 1927 and Aelita. Secondly, well-known director Lev Vladimirovich Kuleshov, who is famous with 'Kuleshov Effect' editing experiment and was a teacher of directors such as Dziga Vertov and Sergey Mikhailovich Eisenstein in addition to being first person using the word 'editing' in the field of cinema, shot the film The Death Ray (Луч смерти) in 1925 by adapting a work of Alexei Tolstoy. However, the Soviet administration put forward that they could not find enough propaganda and Soviet ideals in this film, and Kuleshov was at odds with the Soviet administration. So he abandoned to shoot the film, and he applied himself to theories of film and cinema. Afterwards, in 1935 three science fiction films were shot. The first one is Loss of Sensation (Гибель сенсации), or alternatively titled Robot of Jim Ripple (Робот Джима Рипль) directed by Alexandr Andriyevsky in 1935. In this film, which is also related to the current debates about artificial intelligence, Engineer Ripple starts to make robots ${ }^{8}$. These robots would help people, and capitalism would be demolished because prices and profit rates would descend beside costs of production. However, workers see them as traitors. Government also pays attention to his project because robots can produce weapons. For this purpose, a top-secret factory is allocated to him. Therefore, Engineer Ripple make robots that work with audio frequencies, instead of artificial intelligence, and he controls them by using his saxophone. Moreover, when he gets drunk, they begin to dance. The second one is Air City (Аэроград) directed by Alexander Petrovich Dovzhenko in 1935. Even it is not a complete science fiction film but it is a futuristic adventure film including plenty of Soviet propaganda and patriotism against hostile Japan. The third one is Cosmic

\footnotetext{
8 The concept of 'robot' was created and first used by Czech science fiction writer Kavel Čapek in his book R.U.R. (Rossum's Universal Robots) in 1920. The word 'robot' is derived from the word 'rabota' which means 'forced labor, angary, slavery, duty' in Old Slavic language, and at the same time, the word 'rabota' (работа) means 'work, labor' in Russian as well (Yıldırım, 2019: 240).
} 
Voyage (Космический рейс) directed by Vasily Zhuravlev in 1935 as also a significant science fiction film. This film is a silent film as well as Aelita. While it was shooting, there were many scientists as the advisors on the film set. For example, Tsiolkovsky made 30 drawings of technical rockets for this film. Furthermore, in the film, the cat sent by the second rocket got lost but in the end of the film scientists arriving to the Moon by the third rocket named 'Joseph Stalin' find the cat, and they altogether return to the earth safely. This narration has a reference to 'Schrödinger's Cat' thought experiment of Austrian physicist Ervin Schrödinger as a much-debated issue at that time. In addition to that, in the film, two main characters describe themselves as 'astronauts', and the word 'cosmonaut' started to use in the Soviet Union after 1961 (Lewis, 2008: 262). ${ }^{9}$ However, this film faced with censorship, and it has not been watched until 1980s after its display in 1936. In accordance with the spirit of the era, Russian/Soviet science fiction cinema entered a period of recession, as well as science fiction literature. From mid-1930s up to end of 1950s, beginning of 1960s, so few science fiction films could be made. One of them is Mysterious Island (Таинственный остров) directed by Eduard Pentslin in 1941 that was adapted from the work with same title of Jules Verne dated 1874. It was shot as an ordinary entertaining adventure film, which got over the censorship easily, that actually can be identified as proto-science fiction.

In the later 1950s, Russian/Soviet science fiction cinema started to get into action again. The first one is The Secret of Two Oceans (Тайна двух океанов) directed by Konstantine Pipinashvili in 1956, and it is not completely a science fiction film but it gives the sign of the period that films started to treat the agents of enemy countries and top-secret super weapons. Another considerable one is Road to the Stars (Дорога к звёздам) directed by Pavel Klushantsev in 1957. At the same time, this film was the sign that Russian/Soviet science fiction cinema came to light again. It includes a combination of science education films and fictional narrative. Furthermore, when Stanley Kubrick shot his film 2001: A Space Odyssey in 1968, he used many effects and some scenes very similar to this film (Astronautix) such as spacecraft in a shape of wheel, space clothes, padded cockpit, inside and outside of space station telecommunication tools, the scene about getting lost in space, fixed camera on the image, etc. In addition to that, the scenes about landing of spacecraft on the Moon, descending of astronauts a ladder from the spacecraft and first step on the Moon are reminded of the steps of Neil Armstrong on the Moon in 1969 to the audience. Besides, George Lucas considered Klushantsev as the godfather of Star Wars (Sazonov, 2015). In other respects, the main importance of 1957 depended on the crucial move of the Soviet Union that caused to take a step forward in the competition upon the space exploration between the USSR and the USA. Sputnik I launched, and this move was a great step for whole humanity. Hence, the key of the space age was on the hands of the Soviet Union. After this historical move, number of science fiction films also started to increase. In 1959, three significant films were shot. The initial one is I Was a Satellite

\footnotetext{
${ }^{9}$ Although the words 'astronaut' and 'cosmonaut' have an identical meaning, these words are used differently because of the rivalry between the USSR and the USA due to the space researches. Both of them are Greek-based words: 'Cosmos' means 'universe', 'astro' means 'star', and 'naut' means 'voyager' in Greek.
} 
of the Sun (Я был спутником Солнца) directed by Yuri Merkulov, and it is a dramatic science fiction film including some animation items. The second one is a joint SovietFinnish film directed by Alexander Ptushko and known as Sampo (Сампо) in the Soviet Union and The Day the Earth Froze in the international arena. The story depends on the Finnish national saga Kalevala, and it is actually a cult fantastic film instead of being a science fiction film. The last one is a horror science fiction film titled as The Sky Calls / The Heavens Beckon (Небо зовет) directed by Valery Fokin. This film is about the rivalry between the USSR and the USA on Mars. However, on the date of the film, neither Yuri Gagarin goes to the space nor Neil Armstrong steps on the Moon. On the other hand, Francis Ford Coppola made some changes such as altering the names, using items belonging to NASA, removing the Soviet-American conflict, erasing the Russian scripts, adding monsters, etc., and then the film with a new title as Battle Beyond the Sun was released again in 1962.

After Yuri Gagarin became the first person in the space in the year of 1961, the rivalry between the USSR and the USA upon the space researches began to rekindle. Being well ahead of the Soviet Union in this field also reflected in from daily life to science and arts. In other words, "from the 1960s onwards [...] socialist realism feel from grace and was gradually replaced by the bytovoy (slice-of-life) film [... that] told stories 'about contemporary society, individual lives and relations, current problems and human values"' (Isaacs, 2018: 63). Therefore, by 1960s and 1970s, works in both science fiction literature and cinema showed an increase quantitatively and qualitatively. The first significant film of 1960s is Klushantsev's film Planet of Storms (Планета Бурь) dated 1962. In this film, a sense of mission arisen by representing Soviet high values together with the seriousness of science education as the general approach of Klushantsev attracted the attention. Another film dated 1962 is Amphibian Man (Человек-амфибия) directed by Vladimir Chebotaryov and Gennadiy Kazanskiy as the adaptation of Belyaev's popular work. Both this novel and this film became cults in Soviet geography. After Gagarin went to space successfully, Russian/Soviet science fiction films could treat space journeys more confidently. One of these films is $A$ Dream Come True (Мечmе навстречу) directed by Mikhail Fyodorovich Karyukov, who was also producer of The Sky Calls / The Heavens Beckon, in 1963. This film, which was produced by having paid a lot of money, tells that Soviet cosmonauts go to help a spacecraft coming from the depth of universe to the Earth after a forced landing on Mars because of a malfunction in the spacecraft. Subsequently, another film, which is adapted from the significant novel of Alexei Tolstoy, is Hyperboloid of Engineer Garin (Гиперболоид инженера Гарина) and directed by Alexandr Gintsburg in 1965. Another adaptation from a novel is The Andromeda Nebula (Туманность Андромеды) of Ivan Antonovich Efremov that was shot by Evgeniy Sherstobitov in 1967. Initially it was considered to shoot as a serial but after the death of the leading actor Sergey Stolyarov this plan was abolished. Additionally, another film dated 1967 is They Called Him Robert (Его звали Роберт) directed by llya Olshvanger. In this film, it tells that a cyborg named as Robert created by a scientist as his double becomes a human than any human being. In 1968, Klushantsev directed a film titled as Mars (Mapc) as a follow-up of his film The Moon (Луна) shot in 1965. These two films are also composed of science fiction narration and science education as Klushantsev's general approach 
in his films. There are two parts of both these two films: The first part includes scientific information about the Moon and Mars; the second part contains science fictional and fantastic items such as colonization on the Moon and Mars in the future and probable life forms on Mars.

By the 1970s, science fiction cinema started to incline towards the productions that go beyond documentarily science education or narratives upon heroism, patriotism and indestructible faith in their country and science of homo-Sovieticus comrades. Moreover, obvious examples of this fact were given by Andrei Arsenyevich Tarkovsky. He directed two science fiction films. The first one is Solaris (Солярис) dated 1972 and the other is Stalker (Сталкер) dated 1979. Solaris, which was adapted from the famous work of Lem, was first shot as a film in 1968 by Boris Nirenburg as a television film composed of two episodes. However, the version shot by Tarkovsky acquires worldwide fame and becomes one of the prominent science fiction films of all time. This might be a proof that Tarkovsky is one of the most significant and talented directors in the cinema world. His other science fiction film Stalker is an adaptation of Strugatsky Brothers' Roadside Picnic. This film also becomes a masterpiece in the history of cinema. Since it was shot, it leaves many impressions not only in science fiction or in arts but also in daily life as a consequence of that it is watched with admiration by thousands of people across the world. Another science fiction television film composed of four episodes is Failure of Engineer Garin (Крах инженера Гарина) directed by Leonid Aleksandrovich Kvinikhidze in 1973. This film was inspired of Alexei Tolstoy's Hyperboloid of Engineer Garin. In addition to that, another film dated 1973 is Budimir Metalnikov's Silence of Doctor Ivens (Молчание доктора Ивенса). This film is about a scientist who accidentally encounters and get in contact with aliens. One other film dated 1973 is Ivan Vasilyevich Changes His Profession or Ivan Vasilievich: Back to the Future (Иван Васильевич меняет профессию) directed by Leonid Gayday. This film, which is a comedy science fiction film, is still a well-known film watched and loved so much within the post-Soviet geography. It is an adaptation of Ivan Vasilyevich a play of Bulgakov that was written in 1935 but was published in 1965. It is about comedy emerging as a result of that Engineer Shurik, who works on a time machine, accidentally replaces apartment building manager Ivan Vasilyevich with Ivan the Terrible. Furthermore, another comedy science fiction films are Richard Viktorov's Moscow-Cassiopeia (Москва - Кассиопея) dated 1973 and its sequel Teens in the Universe (Отроки во вселенной) dated 1974. These films, which combine comedy and science fiction successfully, are actually made for children and teenagers. One of two films shot in 1975 is Mikhail Shveytser's The Flight of Mr. McKinley (Бегство мистера Мак-кинли) and other is Valentin Selivanov's A Great Space Voyage (Большое космическое путешествие). The first one is a criticism of capitalism through telling self-alienation and derealization of the individual. The second one is a children-directed science fiction film that handles space voyages of three children. Besides, soundtracks of $A$ Great Space Voyage was composed by famous composer Alexey Lvovich Rybnikov, and 'Of Course I Believe You' (Я тебе конечно верю) as one of the songs of this film has caught on for a long time in Soviet geography. In 1978, there are two science fiction films. These are Vladimir Tarasov's Contact (Контакт), which is a cartoon/animated science fiction film, and Marek Piestrak's Inquest of 
Pilot Pirx (Дознание пилота Пиркса). The second one is a joint Soviet-Polish film, and it was shot by being based upon a story story titled as 'The Investigation' of Lem in his book Tales of Pirx the Pilot. In 1979, again there emerge two films on the screen. These are The Aquanauts (Акванавты) directed by lgor Voznesensky and Dead Mountaineer's Hotel (У погибшего альпиниста) directed by Grigori Kromanov that is based on the novel with same title of Strugatsky Brothers. For Russian/Soviet science fiction cinema, 1970s became a period that cinema harmonized with arts, literature, philosophy, music and science much more rather than being merely scientific documentaries or education films. It was also an epoch such that on the one hand there were professional shootings, powerful scenes, influential soundtracks, etc., and on the other hand various kinds of productions, which addressed young and old everyone, were made.

In 1980s, there were produced science fiction films much more than 1960s and 1970s. On the one side, while there was a critical oil crisis all over the world, the Soviet Union, which was one of the prominent oil exporting countries, benefited from the arisen prices of oil and increased its revenue in both cash and loan based. On the other hand, there emerged a more appropriate sphere for films and other artistic works because hegemony of the state and the Party depending on a strict Soviet ideology began to soften. Together with appearing economic and political relief, especially by the mid-1960s Soviet intelligentsia started to bring into view themselves, their works, their thoughts and their dissidences, so there arose new kinds of conditions that would provide a sphere, which necessitates the potentialities for free and independent imaginations, to Soviet society in 1970s and 1980s. Furthermore, Russian/Soviet science fiction cinema also took advantage of this kind of sphere. The first film of this era is a popular children's television mini-series The Adventures of the Electronic (Приключения Электроника) directed by Konstantin Bromberg in 1980. It was watched by Soviet children interestedly and with pleasure. Another film belonging to 1980 is Star Inspector (Звездный инспектор) directed by Mark Kovalyov and Vladimir Polin. It was about Soviet space polices in pursuit of capitalist space pirates. The third film of the 1980s is Orion's Loop (Петля Ориона) of Vasiliy Levin. The source of inspiration of the title of the film is 'Barnard's Loop' on the Orion Nebula also as the first thing comes to the minds when Orion and loop were mentioned. Another cult film in Soviet geography is Per Aspera Ad Astra or Through the Thorns to the Stars (Чере3 тернии к звездам). It is first directed by Richard Viktorov in 1981, and then his son Nikolay Viktorov shot again in 2001 for its 20th anniversary. The title of the film 'per aspera ad astra' is a very famous Latin phrase and it means 'through hardships to the stars'. This iconic phrase was also written on the memorial tombs of the crew of Apollo I that passed away in an accident in 1967 before launching. Another film dated 1981 is a cartoon/animation science fiction film Mystery of the Third Planet (Тайна третьей планеты) directed by Roman Kacharov. This film also became a cult among Soviet children then because of being both cartoon and science fiction film. In 1982, Bromberg directed the film Charodei (Чародеи) based on Strugatsky Brothers' book Monday Begins on Saturday. Although the film diverged from the book and inclined to fantasy much more than science fiction, it might be considered as a science fiction as well. The films of 1984 are Pavel Arsenov's Guest from the Future (Гостья из будущего), which 
is a children's television serial with 5 episodes, Leonid Menaker's Professor Dowell's Testament (Завещание профрессора Доуэля), which is based on Belyaev's book The Head of Professor Dowell, and Vadim Abdrashitov's Parade of the Planets (Парад планет), which is about parade of planets as a rare astrological event and has a very similar style with Tarkovsky's Stalker. In 1985, there is a cartoon/animation science fiction short film titled as Contract (Контракт) and directed by Tarasov. One of the films of 1986 is also another so popular film all along the Soviet Union. It was shot by Georgy Daneliya and titled as Kin-Dza-Dza! (Кин-дза-дза!). In 2013, Daneliya made a cartoon/animation version of this film titled as Ku! Kin-Dza-Dza (Кy! Кин-дза-дза) as well. Kin-Dza-Dza! is a dystopian and dark comedy film distinct from the science fiction films in the Soviet Union until then. At the same time, although dark comedy and satire became widespread and influential in Soviet society through the works of dissident intellectuals, these approaches could not find a place in cinema that was inspected and controlled by official organs under the roof of the state because it had a significant impact on public. Another film of 1986 is Letters from a Dead Man (Письма мёртвого человека) shot by Konstantin Lopushansky. Fitting with the spirit of those days, it tells a story on a narration of a scientist who can survive after a nuclear war about the past events that occur on road to the war. Films made in 1987 are Andrey Yermash's The End of Eternity (Конец Вечности) based on Asimov's work with same title, Pavel Arsyonov's The Lilac Ball (Лиловый шар), which is a children science fiction film, and Nazim Tulyakhodzayev's Veld (Вельд) based on ray Bradbury's work with same title. 1988 was a very active year for science fiction cinema. There were six films: Karen Shakhnazarov's Zerograd (Город Зеро); Aleksandr Sokurov's Days of Eclipse (Дни затмения); Tarasov's The Pass (Перевал), which is a cartoon/animation science fiction film; Vladimir Khotinenko's Mirror for a Hero (Зеркало для героя), which is also an interesting philosophical film about that main characters go to past accidentally through time travel and they spend their days with same date every day, and Vladimir Bortko's Heart of a Dog (Собачье cepдue) based on Bulgakov's work with same title. The year of 1989 became sign of that everything has started to change and nothing would be same anymore not only for economic, political and social situations but also for science fiction cinema. Films of those days are Lopushansky's masterpiece Visitor of a Museum (Посетитель музея), which is also a dystopian/post-apocalyptic film, and Yuriy Moroz's The Witches Cave (Подземелье ведьм), which is composed of both fantastic and science fictional items. Another significant film shot in this year is Hard to Be a God (Трудно быть богом) based on the novel of Strugatsky Brothers with same title. Actually it was started to be shot by Alexei German in 1968 but he could not complete it because Red Army entered Prague and it caused a crucial political crisis in national and international scale. In 1989, it was shot by Peter Fleischmann as a joint Germany-Switzerland-USSR Project with title of Es ist nicht leicht, ein Gott zu sein. Later, Alexei German Jr., son of Alexei German completed the film his father left unfinished, and the film was released in 2013. Afterwards, for a long time any science fiction films have not been shot within this geography. By the collapse of the USSR in 1991 after the dissolution of Warsaw Pact in 1989, the transition process towards the construction of capitalism has begun. However, capitalism could not provide either prosperity or liberty to the Russian society. On the contrary, 1990s 
became indeed a catastrophic era for most of the Russian population who lost what they had possessed previously.

It needed to elapse few years in the 2000s for recovery of Russian society, which had many traumatic memories belonging to 1990s. In parallel with political, economic and social life, cultural and artistic sphere also suffered from the crises emerge in all areas in life of Russian society. Therefore, science fiction cinema took a long pause from end of the 1980s to 2000s as well. After many years, in 2004 there emerged new films in this sector. The first one is Timur Bekmambetov's Night Watch (Ночной дозор), which is a mythological-fantastic film rather than a science fiction and an action film having a Hollywood impression a little bit too much. In the course of time, Russian cinema also transformed a lot, and it lost its artistic/aesthetical attributes but gained an approach focuses on market and consumption. This film was a good example of this new fact as one of the crucial aspects of new order in Russia. In 2005, at last a real science fiction film was shot. It is Aleksey Fedorchenko's First on the Moon (Первые на Луне), which is blended documentary and fiction. Afterwards, there is a children's science fiction film directed by Oleg Kompasov in 2006 with the title of Asiris Nuna (Азирис Нуна). The title of the film means 'good night' in Ancient Egyptian. Another one dated 2006 is The Ugly Swans (Гадкие лебеди) based on Strugatsky Brothers' work with same title. It was shot by Lopushansky, who assisted Tarkovsky in his film Stalker. Moreover, not only this film indeed attracted attention of audience so much but also it was compared with Tarkovsky's Stalker in respect of philosophical and existentialist arguments in the film. Subsequently, the film shot and released in 2007 is Paragraph 78 (Параграф 78) directed by Mikhail Khleborodov. It is composed of two parts as $1^{\text {st }}$ film and $2^{\text {nd }}$ film. Although it includes impact of Hollywood action films to a degree, it is one of the significant contemporary Russian science fiction films in the post-Soviet era. In 2007, Fedorchenko shot The Railway (Железная дорога). This film is about conflict of old and new Russia on the one hand, and upon intertwining of real and illusion, fantasy on the other hand. Another film adapted from Prisoners of Power as one of the works of Strugatsky Brothers is The Inhabited Island or Dark Planet (Обитаемый остров) directed by Fedor Bondarchuk in 2008. During its release time, it became very popular, and although it includes handsome Vasiliy Stepanov as the leading actor and some latest action scenes, it can be the film, which came up to Soviet science fiction film among the films shot after 2000. Moreover, another factor of increasing its popularity was hit song 'I Believe' (Верю я) of Russian famous rock band Tokio (Токио). In 2009, there was a children's cartoon/animation science fiction film with an old Soviet style that was titled as Alice's Birthday (День рождения Алисы) and directed by Sergey Seryogin. In 2011, there were two films: Chris Gorak's joint RussiaUSA film The Darkest Hour (Самый тёмный час); and Alexander Zeldovich's Target (Мишень). Both of them use science fiction as a scenery. The first one is a typical Hollywood film; the second one is a satire that ridicules with extremely rich but uncouth and uncultured 'New Russians' (Новые Русские) emerged by the 1990s in the transition process of Russia. Later, there was another joint Russia-USA film Hardcore (Хардкор) directed by llya Naishuller in 2015. It is full of sexuality, female bodies, masculinity, narcotics, vulgarism, violence, weapons and blood, and again science fiction is just a scenery in the film. The recent significant science fiction film is 
Bondarchuk's Attraction (Притяжение) shot in 2017. According to the director Bondarchuk, it was a social allegorical narration, and in some sort, it tells about antiimmigrant 'Biryulyovo riots' (Беспорядки в Западном Бирюлёво) occurred in 2013. Apart from these, up to the present many science fiction films have been shot but in fact these are not enough unique or qualified to mention, rather they are made for entertaining the masses.

Therefore, Russian/Soviet science fiction cinema undergoes an ever-changing process from the first film to the last film recently shot. As all fields of art, this change is influenced by daily life, social events, political issues, economic circumstances and cultural facts. However, the main structure of Russian/Soviet cinema depends on the reciprocal dialectical relationship of two basic mechanisms generating ironic and contradictory states of Russian society. The first one is the cumulative accumulation in the fields of arts such as literature, music, ballet, theater and cinema that consist of the framework of the Russian culture. The second one is traditional patriarchal/patrimonial and authoritarian attributes of the power and intelligentsia against this power and existence of their hibernator political and social opposition affects arts, literature and cinema as well as all sphere of life within the atmosphere created by politisationdepolitisation-repolitisation process, which makes way in a cycle in Russian geography for nearly two centuries. It is possible to see the first in the works such as ones of Lopushansky or Tarkovsky. For the second one, it can be exemplified by the works such as Klushantsev's film Planet of Storms, Karyukov's A Dream Come True or Bekmambetov's Night Watch. Apart from that, it is also interesting that some title of these works includes Western person names such as Jim Ripple, Robert, Ivens, Mr. McKinley, Professor Dowell and Alice, and they were produced in a country as the leading actor of socialist alliance throughout the world and the main rival of the Western world.

\section{Conclusion}

German physiologist Emil du Bois-Reymond used the Latin phrase 'ignoramus et ignorabimus', which means 'we do not know and we will not know', to describe the finiteness of human reason and science, and it can be seen as a sense attitude against the lust and irresistibility of desire of human beings for completely ruling over the nature and the universe. Science fiction can be considered as an endeavor for revealing the potential consequences of these anthropocentric scenarios within a scientific and philosophical framework. Especially transformation of confidence in human reason to a megalomania by the fact that science and technology becomes a way of dominating and controlling the nature and the universe instead of goal of comprehending them manifests the requirement of this attitude. Furthermore, human beings get involved in a process of recognition permanently mediating issues surrounds them, and so, everything and everyone beside them easily become a 'means' to use for their ends in this process (Dişçi, 2018: 369). For this reason, science fiction is not only an artistic topic but also a narrative possesses historical, political, social, cultural and philosophical background as well. On the one side, some of the significant aspects of this genre have been exhibited in the Soviet Union, where science and technology became a political and social cult. On the other side, the Soviet Union becomes one of the prominent inspiration sources of science fiction works all over the world. In this 
sense, science fiction has also two essential attributes: As the first one, it is an important socio-cultural fact in such geography, where a society that tried to construct an unattempted system through own certain values and principles was in a course of building a new culture; and as the second one, it causes the possibility of synthesis of science and arts that both take crucial places historically and socio-culturally. Because of that reason, from these lands, an entire corpus is constituted of rich content contains many artists some of whom are mentioned above. Moreover, in Russian geography, science fiction has also been treated in and/or with many areas such as music, modern dance, ballet, theater, painting, sculpture, etc. as well as in literature and cinema. On the other hand, it is obvious that 'scientific socialism' consideration in the USSR could also provide a suitable ground for science fiction works (Sterling, 2019). The artists producing science fiction works have benefited from the view due to the possibility of socialism, which was tried to construct in Russian geography, by following the line generated by science and technology with regards to produce original contents, publish or release works without facing some certain restrictions to some extent and create opportunities to reach the masses. Therefore, in this work, it was tried to discuss most of these aspects of Russian/Soviet science fiction gives works in literature and cinema by examining the circumstances, in which these works were produced, because these works have also reflected not an only economic, political and social situation of the Soviet Union or Russia but also ideas, opinions, feelings, living conditions of Russian society, and the impacts of these works provide a new kind of perspective to understand the Russian geography much extensively from past to today. In fact, currently the whole world begins to experience the realization of dystopian projects, as distinct from the utopian projections emerged and proceeded for the last two centuries but ends as a result of faults and failures of human beings. However, as Strugatsky Brothers state, maybe the cause of all chaos today we experience is that "it's not [... us], it's the universe!" because it is against us for "defending itself" indeed:

Vecherovsky introduced the concept of the Homeostatic Universe. "The universe retains its structure," that was his fundamental axiom. [...] If only the law of non-decreasing entropy existed, the structure of the universe would disappear and chaos would reign. But on the other hand, if only a constantly self-perfecting and all-powerful intelligence prevailed, the structure of the universe based on homeostasis would also be disrupted. This, of course, did not mean that the universe would become better or worse - merely different - contrary to the principle of homeostasis since a constantly developing intelligence can have but one goal: to change nature. That is why the gist of the Homeostatic Universe consists in maintaining the balance between the increase in entropy and the development of reason. That is why there are no and can be no supercivilizations, since the term supercivilization is used for intelligence developed to such a degree that it transcends the law of non-decreasing entropy on a cosmic scale. And what was happening to us now was nothing other than the first reaction of the Homeostatic Universe to the threat of humanity becoming a supercivilization. The universe was defending itself (Strugatsky \& Strugatsky, 2014: 89-90). 


\section{REFERENCES}

ASTRONAUTIX, "Road to the Stars", http://www.astronautix.com/r/roadtothestars.html (21.06.2020).

BANERJEE, A. (2012). We Modern People: Science Fiction and the Making of Russian Modernity. Middletown CT: Wesleyan University Press.

BUCK-Morss, S. (2000). Dreamworld and Catastrophe: The Passing of Mass Utopia in East and West. Cambridge and London: MIT Press.

CHRISTENSEN, P. G. (2000). Women as Princesses or Comrades: Ambivalence in Yakov PROTAZANOV'S “Aelita” (1924). New Zealand Slavonic Journal, 107-122.

CHERNYSHEVSKY, N. (1989). What is to be Done? (Trans. by M. R. Katz). Ithaca and London: Cornell University Press.

Dişçi, Z. (2018). İnsan ve Vampir: Sadece Âşıklar Hayatta Kalır Filminde Varlığın Spinozacı Temsili. Art-Sanat Dergisi, 9, 367-384

GEZGiN, U. B. (2016). Devrim Öncesi Edebiyatında Ütopya: Kızıl Yıldız Örneği. Evrensel Kültür Dergisi, 298, 86-89.

ISAACS, R. (2018). Film and Identity in Kazakhstan: Soviet and Post-Soviet Culture in Central Asia. London-New York: I. B. Tauris.

LANDON, B. (2002). Science Fiction after 1900: From the Steam Man to the Stars. New York: Routledge.

LEWIS, C. S. (2008). From the Cradle to the Grave: Cosmonaut Nostalgia in Soviet and Post-Soviet Film. In S. J. Dick (Ed.), Remembering the Space Age (pp. 253-270). Washington DC: NASA.

SAZONOV, A. (2015). Seven Soviet Sci-Fi Films Everyone Should See. Guardian, 28.04.2015, https://www.theguardian.com/world/2015/apr/28/cinema-seven-soviet-scifi-films (28.06.2020).

STERLING, B. (2019). Science Fiction. Encyclopædia Britannica, 11.09.2019, https://www.britannica.com/art/science-fiction (05.07.2020)

STRUGATSKY, A. \& Strugatsky, B. (2014). Definitely Maybe (Trans. by A. W. Bouis). New York \& London: Melville House Publishing.

YILDIRIM, E. (2014). Sovyetler Birliği'nde Propaganda ve Proleter Hegemonik İdeolojinin Kurulumu Üzerine. Doğu-Batı Dergisi, 64, 271-293.

YILDIRIM, E. (2016). Rus Gerçekçi Edebiyatının Ekim Devrimine Giden Sürece Etkileri ve Katkıları. Evrensel Kültür Dergisi, 298, 63-68.

YILDIRIM, E. (2019). Yapay Zekânın Ekonomi Politiği. In H. Sağlam \& C. Peker (Eds.), If Globalism is Dead- Long Live What? - Abstracts \& Proceedings (pp. 239-247). 10. ICOPEC 2019: International Conference of Political Economy, June 25-28, 2019, İstanbul. 